\title{
Mutu Organoleptik Abon Ikan Roa Asap Dari Desa Bahoi Kecamatan Likupang Barat Kabupaten Minahasa Utara
}

\author{
Helen Jenny Lohoo* dan Joyce Ch. V. Palenewen \\ Fakultas Perikanan dan Ilmu Kelautan, Universitas Sam Ratulangi. \\ J1. Kampus Unsrat Bahu, Manado 95115, Sulawesi Utara, Indonesia. \\ *Penulis Korespondensi: helen lohoo@unsrat.ac.id \\ (Diterima 17-10-2019; Direvisi 23-11-2019; Dipublikasi 11-01-2020)
}

\begin{abstract}
The utilization of smoked roa into a final product is still very limited, so it is necessary to diversify the smoked roa by processing to become shredded products. Processing smoked roa into shredded will give practicality to consumers in consuming ready-to-eat roa fish. This product has a soft texture, distinctive taste and aroma. Abon making is one alternative to fish processing. This is done to anticipate abundance of production or to diversify fishery products. In this process, fish made in shredded fish are smoked roa which are treated by using a spinner and without using a spinner machine, while panelists are women who process the shredded smoked roa and several woman in Desa Bahoi. Organoleptic test results and the quality of shredded smoked roa fish produced by coastal women of Desa Bahoi, Likupang Barat, Kabupaten Minahasa Utara showed that the panelists gave an average response very like and extremely like (grades 8 and 9) on the taste, aroma and texture of shredded roa which is drained using a spinner machine. For other tests such as water content, and the Total Plate Count the results still meet the requirements of Indonesian National Standard (SNI) for shredded products in general.
\end{abstract}

Kata kunci: potensi, abon, diversifikasi, pemberdayaan.

\begin{abstract}
ABSTRAK
Pemanfaatan ikan roa asap menjadi produk masih sangat terbatas, maka dari itu perlu dilakukan diversifikasi ikan roa asap dengan salah satu cara pengolahan produk abon. Pengolahan ikan roa asap menjadi abon akan memberi kepraktisan pada konsumen dalam mengkonsumsi ikan roa siap saji. Produk ini mempunyai tekstur yang lembut rasa dan aroma yang khas. Pembuatan abon merupakan salah satu alternatif pengolahan ikan. Hal ini dilakukan untuk mengantisipasi kelimpahan produksi ataupun untuk penganekaragaman produk perikanan. Pada kegiatan ini ikan yang dibuat abon adalah ikan roa asap yang diberi perlakuan diperas menggunakan spinner dan tanpa menggunakan mesin spinner, sedangkan panelis adalah ibu ibu yang mengolah abon ikan roa asap dan beberapa ibu lainnya yang ada di desa Bahoi. Hasil uji organoleptik dan mutu abon ikan roa asap yang diproduksi oleh perempuan (ibu-ibu pesisir) desa Bahoi Kecamatan Likupang Barat Kabupaten Minahasa Utara Provinsi Sulawesi Utara memperlihatkan bahwa panelis memberikan respon rata-rata sangat suka dan amat sangat suka (nilai 8 dan 9) terhadap rasa, aroma dan tekstur produk abon ikan roa asap yang dilakukan penirisan minyak menggunakan mesin spinner. Untuk pengujian lainnnya seperti Kadar air, dan Total Plate Count memberikan hasil memenuhi Standar Nasional Indonesia (SNI) untuk produk abon pada umumnya.
\end{abstract}

Kata kunci: potensi, abon, diversifikasi, pemberdayaan.

\section{PENDAHULUAN}

Pemberdayaan kaum wanita (ibu dan putri) nelayan untuk kegiatan ekonomi yang berbasis usaha perikanan, diperkirakan akan menjadi lokomotif baru dalam membawa ekonomi masyarakat nelayan yang lebih sejahtera. Keterampilan para wanita dapat ditingkatkan dengan memberi pelatihan pembuatan komoditi baru berbasis ikan. Disisi lain diversifikasi komoditi perikanan menjadi produk pangan yang sudah dikenal tidak saja sangat aplikatif, tetapi juga akan mempermudah pemasaran.

Prosentase wanita yang umumnya lebih besar daripada laki-laki di daerah pesisir pantai Kabupaten Minahasa Utara lebih khusus Desa Bahoi merupakan potensi yang besar untuk meningkatkan pendapatan masyarakat nelayan, posisi wanita yang selama ini hanya berfungsi sebagai ibu rumah tangga ditingkatkan sebagai penopang ekonomi rumah tangga.

Potensi perikanan tangkap yang ada di Kabupaten Minahasa Utara cukup besar. Untuk Kecamatan Likupang Barat termasuk didalamnya desa Bahoi potensi perikanan tangkapnya adalah ikan dasar dan ikan pelagis. Umumnya hasil tangkapan nelayan adalah jenis ikan pelagis seperti 
julung-julung (Hemirhamphus far), tude, deho cakalang, madidihang dan malalugis. (DKP Minahasa Utara, 2015). Ikan Julung-julung, atau yang dikenal oleh masyarakat dengan nama lokal ikan Roa. biasanya ditangkap untuk dijadikan produk ikan asap.

Diversifikasi produk olahan ikan sangat beragam (Mustar, 2013) misalnya abon ikan, bakso ikan, dendeng ikan, ikan asap, produk fermentasi ikan, dan lain-lain. Pada prinsipnya proses pengolahan tersebut bertujuan untuk meningkatkan daya simpan ikan serta meningkatkan nilai jualnya sehingga akan meningkatkan kesejahteraan keluarga nelayan.

Pemanfaatan ikan roa asap menjadi produk masih sangat terbatas, maka dari itu perlu dilakukan diversifikasi ikan roa asap dengan salah satu cara pengolahan produk abon. Pengolahan ikan roa asap menjadi abon akan memberi kepraktisan pada konsumen dalam mengkonsumsi ikan roa siap saji. Abon ikan merupakan produk yang memadukan cara pengawetan ikan dengan perebusan atau pengukusan, penambahan bumbu-bumbu tertentu dan penggorengan. Produk ini mempunyai tekstur yang lembut rasa dan aroma yang khas.

Berdasarkan permasalahan yang dikemukakan di atas maka dilakukan penelitian terhadap uji organoleptik/tingkat kesukaan panelis terhadap abon ikan roa asap yang diproduksi oleh kaum perempuan atau ibu-ibu yang ada di Desa Bahoi Kecamatan Likupang Barat Kabupaten Minahasa Utara Provinsi Sulawesi Utara melalui kegiatan PKM Pemberdayaan Kelompok Perempuan Pesisir Desa Bahoi.

Pembuatan abon merupakan salah satu alternatif pengolahan ikan. Hal ini dilakukan untuk mengantisipasi kelimpahan produksi ataupun untuk penganekaragaman produk perikanan. Berdasarkan SNI 01-3707-1995, abon merupakan hasil pengolahan yang berupa pengeringan bahan baku yang telah ditambahkan bumbu-bumbu untuk meningkatkan cita rasa dan memperpanjang daya simpan. Jenis ikan yang dibuat sebagai bahan baku jenis abon belum selektif, bahkan hampir semua jenis ikan dapat dijadikan abon. Namun demikian, akan lebih baik bila dipilih jenis ikan yang mempunyai serat yang kasar dan tidak mengandung banyak duri. Sejauh ini ikan yang dibuat abon adalah ikan roa asap yang diberi perlakuan diperas menggunakan spinner dan tanpa menggunakan mesin spinner, sedangkan panelis adalah ibu-ibu yang mengolah abon ikan roa asap dan beberapa ibu lainnya yang ada di desa Bahoi.

\section{HASIL UJI PREFERENCES}

\section{Rasa}

Hasil penelitian terhadap nilai rasa abon ikan roa asap dengan penirisan menggunakan mesin spinner dan tanpa menggunakan mesin spinner memberikan hasil yang non signifikan. Dari 20 orang panelis rata-rata memberikan respon sangat suka terhadap abon ikan roa asap. Rasa merupakan faktor yang penting dalam menentukan penerimaan atau penolakan konsumen terhadap suatu bahan pangan. Meskipun tekstur bahan pangan baik namun jika rasanya tidak enak maka konsumen akan menolak produk tersebut (Winarno, 2004).

Menurut Soekarto (1985), rasa makanan yang kita kenal sehari-hari sebenarnya bukanlah satu tanggapan, melainkan campuran dari tanggapan cicip, bau dan trigeminal yang diramu oleh kesan-kesan lain seperti penglihatan, sentuhan, dan pendengaran. Jadi, kalau kita menikmati atau merasakan makanan, sebenarnya kenikmatan tersebut diwujudkan bersama-sama oleh kelima indera. Peramuan rasa itu ialah suatu sugesti kejiwaan terhadap makanan yang menentukan nilai pemuasan orang yang memakannya.

\section{Tekstur}

Nilai tekstur abon ikan roa asap dengan perlakuan penirisan dengan mesin spinner didapatkan perlakuan terbaik, dengan karakteristik tekstur abon mempunyai serat yang kasar dan lembut serta kering. Pengamatan tekstur pada abon ikan sangat penting dilakukan. Hal ini disebabkan karena tekstur merupakan salah satu hal yang membedakan abon ikan dengan produk perikanan lainnya yaitu berupa serat-serat yang lembut. Tekstur daging sangat berpengaruh terhadap produk akhir yang dihasilkan dan menentukan tingkat kesukaan konsumen terhadap produk tersebut (Sulthoniyah et.al., 2013).

\section{Aroma}


Menurut Kartika et.al., (1988) aroma dapat didefinisikan sebagai hasil dari respon indera pencium yang diakibatkan oleh menguapnya zat-zat sedikit larut dalam lemak pada suatu produk makanan ke udara sehingga dapat direspon oleh indera penciuman dan kemudian dikenali oleh sistem tubuh sebagai aroma tertentu. Selanjutnya menurut Aziz (2012), mengatakan bahwa bau/ aroma merupakan salah satu komponen cita rasa pada makanan. Dengan aroma atau bau, maka dapat diketahui rasa dari makanan tersebut.

Faktor lain adalah karena adanya proses penggorengan. Proses penggorengan menghasilkan warna kuning kecoklatan. Adapun warna kecolatan yang ditimbulkan disebabkan adanya proses karamelisasi. Karamel adalah substansi berasa manis, berwarna cokelat dan merupakan campuran dari beberapa senyawa yang mirip karbohidrat. Sukrosa akan mengalami karamelisasi apabila suhu yang digunakan diatas titik lebur sukrosa. Reaksi maillard adalah reaksi- reaksi karbohidrat, khususnya gula pereduksi dan gugus amina primer. Hasil reaksi tersebut menghasilkan bahan berwarna cokelat yang sering dikehendaki atau terkadang menjadi pertanda penurunan mutu (Rohmawati et.al., 2016).

Respon panelis terhadap aroma memperlihatkan kesan sangat suka akan aroma produk abon ikan roa asap yang khas.

\section{Kadar Air}

Berdasarkan SNI (1995), persyaratan standar mutu abon secara umum nilai kadar air maksimal 7\%, ini berarti kandungan air pada abon ikan roa asap dengan penirisan menggunakan mesin spinner memenuhi standar mutu SNI dengan kadar air $4.8 \%$.

\section{Aspek Mikrobiologi}

Pengujian Total Plate Count (TPC) sampel ikan roa asap yang dilakukan penirisan dengan mesin spinner memberikan hasil $20,4 \times 10^{3} \mathrm{CFU} / \mathrm{g}$.

\section{KESIMPULAN}

Dari hasil pengamatan dan analisis deskriptif yang dilakukan, dapat diambil kesimpulan sebagai berikut:

1. Warna dan rasa abon ikan roa asap sangat dipengaruhi oleh prosedur pembuatan abon, dan sisa kadar minyak yang terkandung pada abon.

2. Tingginya acceptabilitas panelis terhadap abon ikan roa asap disebabkan oleh performa (penampakkan) dan rasa ketajaman bumbu.

3. Dari aspek mikrobiologi, abon ikan roa asap memenuhi standard kualitas SNI.

\section{DAFTAR PUSTAKA}

Aziz, M,Z. 2012. Pengaruh Promosi dan Cita Rasa Terhadap Jumlah Pembelian Ayam Bakar di Rumah Makan Wong Solo Makassar. Sosial Peternakan Universitas Hasanuddin, Makassar.

Kartika, B.P., Hastuti dan W. Supartono, 1988. Pedoman Uji Inderawi Bahan Pangan Pusat Antar Universitas Pangan dan Gizi.

Rohmawati, N, Sulistiyani dan Ratnawati, L. Y., 2016 Pengaruh Penambahan sukun muda Terhadap Mutu Fisik, Kadar Protein, Dan Kadar Air Abon Lele Dumbo (Clarias Gariepinus). Jurnal. Universitas Jember. Jember.

Standar Nasional Indonesia (SNI). 1995. Abon Nomor 01-371995, Dewan, Badan Standarisasi Nasional. Jakarta.

Sulthoniyah, STM, Sulistiyati, TD, dan Suprayitno, E. 2013. Pengaruh Suhu Pengukusan Terhadap Kandungan Gizi dan Organoleptik Abon Ikan Gabus (Ophiocephalus striatus). THPi STUDENT JOURNAL, Vol. I No. 1. Universitas Brawijaya.

Winarno FG.2004 Kimia Pangan dan Gizi. Jakarta: PT Gramedia Pustaka Utama. Jakarta. 